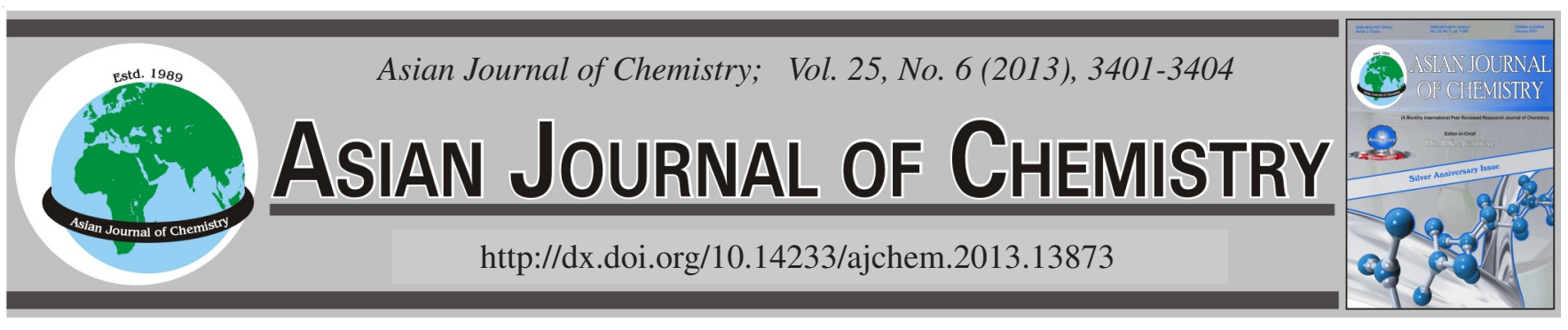

\title{
Effect of Polyethylene Glycol on the Synthesis of Tyr-Arg Dipeptide by $\alpha$-Chymotrypsin in an Organic Medium
}

\author{
Y. HIRANO ${ }^{1, *}$ and Y. NAGAO ${ }^{2}$
}

${ }^{1}$ Department of Chemistry and Materials Engineering, Faculty of Chemistry Materials and Bioengineering, Kansai University, 3-3-35 Yamatecho, Suita, Osaka 564-8680, Japan

${ }^{2}$ Department of Applied Chemistry, Faculty of Engineering, Osaka Institute of Technology, 5-16-1 Ohmiya, Asahi-ku, Osaka 535-8585, Japan

*Corresponding author: Tel/Fax: +81663680974; E-mail: yhirano@kansai-u.ac.jp

(Received: 10 April 2012;

Accepted: 24 December 2012)

AJC-12598

The enzymatic peptide synthesis in an organic medium was investigated using $\alpha$-chymotrypsin in the presence of poly(ethylene glycol)
(PEG). The added PEG enhanced the activity of $\alpha$-chymotrypsin for the synthesis of the peptide Z-Tyr- $\mathrm{Arg}\left(\mathrm{NO}_{2}\right)$-OBzl.. The activity of
$\alpha$-chymotrypsin in the PEG-added system was higher than in a PEG-free system.

Key Words: $\alpha$-Chymotrypsin, Enzymatic peptide synthesis, Michaelis-Menten constant, Non-modified enzyme, Poly(ethylene glycol), Tyr-Arg (Kyotorphin).

\section{INTRODUCTION}

In nature, enzymes function mainly in an aqueous solution. However, over the last few years, many investigations have been carried out enzymatic reactions ${ }^{1-15}$ in an organic solvent. Enzymatic methods of peptide bond formation can broaden the methodological repertoire of peptide chemistry, e.g., proteases to catalyze peptide bond formation may become one of the promising synthetic methods of the future ${ }^{1-19}$. The enzymatic synthesis of peptides proceeds at room temperature in a buffered aqueous-organic solution and, these mild conditions should minimize or eliminate the possibility of side reactions, which might occur in conventional chemical coupling. When proteases are used in direct reversal of their normal hydrolytic function, the chemical equilibrium is very important in limiting the attainable yield in a thermodynamically controlled enzymatic peptide synthesis method. The $N$ and $C$-protected amino acids are sparingly soluble in aqueous media, shifting the chemical equilibrium towards the desired peptide product and the minimization of hydrolytic side reactions are the main reasons for the addition of an organic co-solvent. These reasons are applicable to homogeneous and heterogeneous, aqueous organic media and low water organic reaction systems, respectively. On the whole, the substitution of an organic solvent for water often leads to the destabilization of the protein structure and loss of enzyme activity.

In this report, we described the effects of polyethylene glycol (PEG) on enzymatic peptide syntheses in an organic solvent without forming covalent bonds between the PEG and the enzyme ${ }^{20}$. We applied this system to the synthesis of Kyotorphin by $\alpha$-chymotrypsin and discussed the specificity of the proteases. An amino-protected amino acid was coupled with a carboxyl-protected amino acid to yield a dipeptide product, carbobenzoxy-L-tyrosinyl-Ng-nitro-L-arginine benzyl ester (Z-Tyr-Arg $\left(\mathrm{NO}_{2}\right)$-OBzl), by $\alpha$-chymotrypsin in an organic solvent containing a small amount of water and PEG. The reaction products Z-Tyr, $\operatorname{Arg}\left(\mathrm{NO}_{2}\right)-\mathrm{OBzl}$ and Z-Tyr$\operatorname{Arg}\left(\mathrm{NO}_{2}\right)$-OBzl were examined by gel permeation chromatography (GPC) and the rate of reaction was calculated from the gel permeation chromatography data.

\section{EXPERIMENTAL}

All of the enzymes, chemicals and solvents used were of reagent grade. Carbobenzoxy-L-tyrosine (Z-Tyr) and $\mathrm{Ng}$ nitro-L-arginine benzyl ester $\left(\operatorname{Arg}\left(\mathrm{NO}_{2}\right)-\mathrm{OBzl}\right)$ were purchased from the Peptide Institute (Osaka, Japan). $\alpha$-Chymotrypsin (EC 3.4.21.1; from bovine pancreas, $350 \mathrm{U} / \mathrm{mg}$ ) was from Merck Inc. Polyethylene glycol (PEG), whose molecular weight was about 4,000, was purchased from Wako Pure Chemical Industries (Osaka, Japan). The gel permeation chromatography (GPC) measurements were carried out with a TOSOH GPC system consisting of a CCPD pump unit, a RI8012 RI detector and a TOSOH column (TSK-GEL H type), using THF as mobile phase at a flow rate of $0.7 \mathrm{~mL} \mathrm{~min}^{-1}$.

Preparation of the calibration curves: The calibration curves for the chemical synthesis of the dipeptide Z-Tyr- 
$\operatorname{Arg}\left(\mathrm{NO}_{2}\right)-\mathrm{OBzl}$, were obtained from the relationship between the peptide concentration $(0.3,0.6,0.9$ and $1.2 \mathrm{mmol} / \mathrm{L}$ of THF solution) and the peak area from the GPC chromatograms.

Selection of the reaction solvent: The following organic solvents were tested in this reaction system: PBS (pH: 5-13), methanol, ethanol, dioxane, dimethylformamide (DMF), dimethylsulfoxide (DMSO), tetrahydrofuran (THF), acetonitrile, ethylacetate (saturated with PBS), chloroform (saturated with PBS), 1,1,1-trichloroethane(saturated with PBS) (TCE), benzene (saturated with PBS), toluene(saturated with PBS) and phosphate buffer solution ( $\mathrm{pH} 8.0$, PBS). Z-Tyr $7.5 \times 10^{-2}$ mmol (23.6 mg) and $\operatorname{Arg}\left(\mathrm{NO}_{2}\right)-\mathrm{OBzl} 7.5 \times 10^{-2} \mathrm{mmol}(23.2$ $\mathrm{mg}$ ) were dissolved in $3 \mathrm{~mL}$ of a solvent and then $4 \mathrm{mg}$ of $\alpha$-chymotrypsin and $0.2 \mathrm{~mL}$ of phosphate buffer solution ( $\mathrm{pH}$ 8.0, PBS) were added. The mixture was stirred for $24 \mathrm{~h}$ at $30{ }^{\circ} \mathrm{C}$ to check for the percentage conversion of the reaction. Concentration of substrate $\left(7.5 \times 10^{-2} \mathrm{mmol}\right)$ was the optimum conditions from $0-1.0 \times 10^{-1} \mathrm{mmol}$.

Effects of $\mathrm{pH}$ and amount of PBS for the synthesis of the dipeptide: $\mathrm{Z}-\mathrm{Tyr} 7.5 \times 10^{-2} \mathrm{mmol}(23.6 \mathrm{mg})$ and $\operatorname{Arg}\left(\mathrm{NO}_{2}\right)$ OBzl $7.5 \times 10^{-2} \mathrm{mmol}(23.2 \mathrm{mg})$ were dissolved ethylacetate and PBS, to which $4 \mathrm{mg}$ of $\alpha$-chymotrypsin and PBS (pH: 5$13,0-1.5 \mathrm{~mL}$ ) had been added. The optimal reaction conditions obtained were as follows: $7.5 \times 10^{-2} \mathrm{mmol}$ substrate and 0.2 $\mathrm{mL}$ of PBS ( $\mathrm{pH}=8.0)$ in $3 \mathrm{~mL}$ of ethylacetate.

Synthesis of dipeptides by $\alpha$-chymotrypsin in organic solvents in the presence of PEG: Z-Tyr $7.5 \times 10^{-2} \mathrm{mmol}$ $(23.6 \mathrm{mg})$ and $\operatorname{Arg}\left(\mathrm{NO}_{2}\right)$-OBzl $7.5 \times 10^{-2} \mathrm{mmol}(23.2 \mathrm{mg})$ were dissolved in $3.2 \mathrm{~mL}$ of ethylacetate and PBS, to which $4 \mathrm{mg}$ of $\alpha$-chymotrypsin, PEG (0-20 mg) and PBS (0-1.5 mL) had been added. The optimal reaction conditions obtained were as follows: $7.5 \times 10^{-2} \mathrm{mmol}$ substrate, $0.2 \mathrm{~mL}$ of PBS and $2 \mathrm{mg}$ of PEG in $3 \mathrm{~mL}$ of ethyl acetate. All of the mixtures were stirred for $24 \mathrm{~h}$ at $30^{\circ} \mathrm{C}$. The reaction system was a suspension of ethyl acetate and PBS with constant stirring and PEG was soluble in both ethylacetate and PBS. After evaporating the ethylacetate from the reaction mixture $(0.1 \mathrm{~mL}), 4 \mathrm{~mL}$ of THF was added to dissolve the resultant dipeptide and the insoluble residue was then removed by filtration. The product was finally assayed by gel permeation chromatography.

The effects of the reaction temperature, reaction time and concentration of the substrate on the dipeptide synthesis were investigated in order to find the optimal conditions for yield. The optimal reaction conditions obtained were as follows: 7.5 $\times 10^{-2} \mathrm{mmol}$ substrate and $0.2 \mathrm{~mL}$ of PBS ( $\mathrm{pH} \mathrm{8.0)}$ and $2 \mathrm{mg}$ of PEG in $3 \mathrm{~mL}$ of ethyl acetate. The reaction temperature and reaction time were then checked under these conditions. The initial rates $[\mathrm{v}]$ were calculated for different substrate concentrations $([\mathrm{S}]=10-500 \mathrm{mM})$ and the Michaelis Menten constant $\left(\mathrm{K}_{\mathrm{m}}\right)$ was estimated.

\section{RESULTS AND DISCUSSION}

Preparation of the calibration curves: Fig. 1 shows the calibration curves for the dipeptide Z-Tyr- $\operatorname{Arg}\left(\mathrm{NO}_{2}\right)-\mathrm{OBzl}$ obtained by gel permeation chromatography. The peak areas were directly proportional to the concentrations of the dipeptide in THF. The calibration curve was used to estimate the percentage conversion of the reaction and the concentration of the substrate.

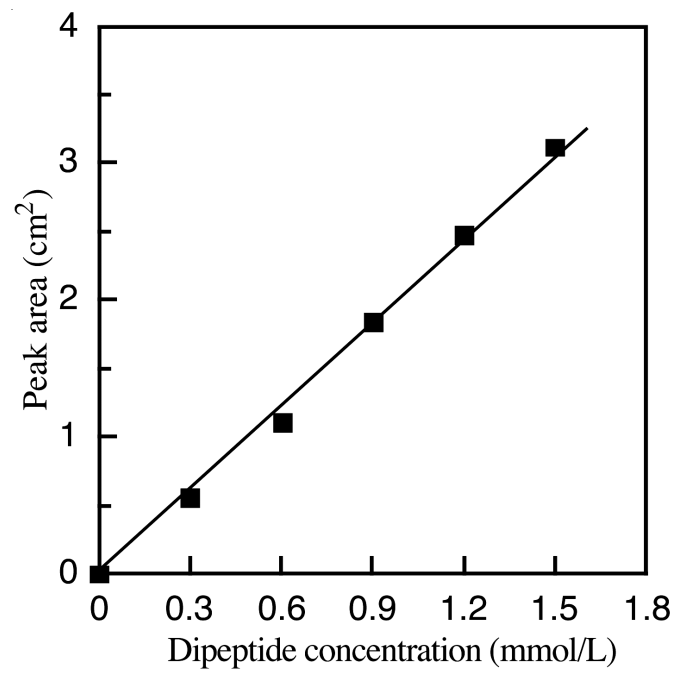

Fig. 1. Calibration curves for the amino acids and dipeptides obtained by GPC. $\square$ Z-Tyr-Arg $\left(\mathrm{NO}_{2}\right)-\mathrm{OBzl}$

Selection of a solvent for the reaction: Ethyl acetate was one of the best solvents for the reaction among the solvents tested. The percentage conversion of the reaction in the solvents tested were PBS: 0-5\%, methanol: $0 \%$, ethanol: $0 \%$, dioxane: $0 \%$, DMF: $0 \%$, DMSO: $0 \%$, THF: $0 \%$, acetonitrile: $0 \%$, chloroform: $40 \%$, TCE: $38 \%$, benzene: $26 \%$ and toluene $25 \%$. These data show that water-miscible solvents were not useful in the reaction system.

Effects of $\mathrm{pH}$ and amount of PBS on the synthesis of the dipeptide: The percentage conversion of the reaction was determined from the GPC tests. Fig. 2 shows the relationship between the percentage conversion of the reaction and the $\mathrm{pH}$ of PBS buffer solution. Fig. 3 shows the relationship between the percentage conversion of the reaction and the amount of PBS buffer solution. The optimal reaction conditions at the point of amount of PBS and solvent for yield obtained were as follows: $7.5 \times 10^{-2} \mathrm{mmol}$ substrate and $0.2 \mathrm{~mL}$ of PBS $(\mathrm{pH}$ $=8.0$ ) in $3 \mathrm{~mL}$ of ethyl acetate.

Enzymatic synthesis of the dipeptide with $\alpha$-chymotrypsin in an organic medium containing PEG: Fig. 4 shows the relationship between the percentage conversion of the reaction and the amount of PEG added in PBS buffer solution

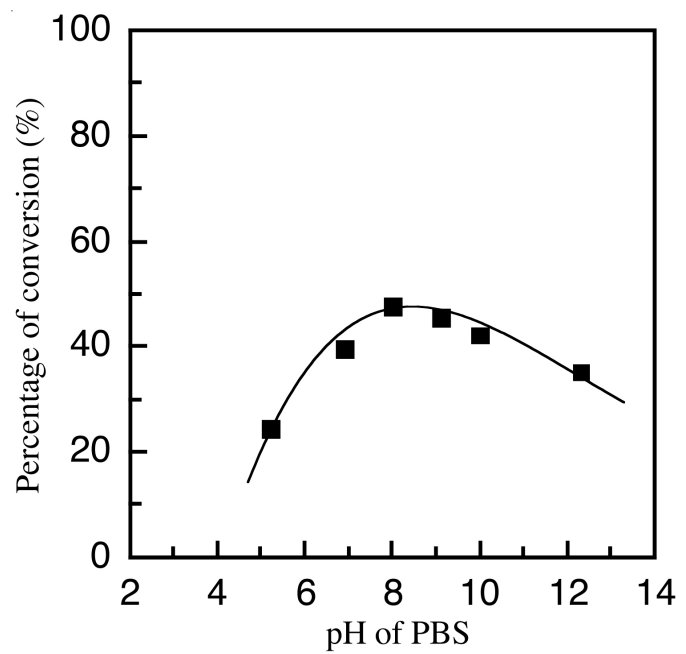

Fig. 2. Relationship between the percentage conversion of the reaction and the $\mathrm{pH}$ of the PBS 


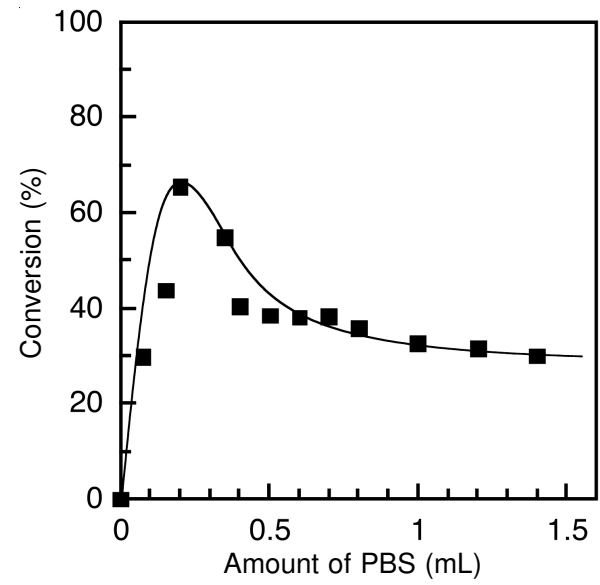

Fig. 3. Relationship between the percentage conversion of the reaction and the amount of PBS

$0.075 \mathrm{~mL}, 0.2 \mathrm{~mL}$ and $\mathbf{\Delta}: 0.5 \mathrm{~mL}$ ). For all of the systems containing PEG, the percentage conversion of the reaction was higher than in the corresponding PEG-free system. As obvious from Fig. 4 the amounts of PBS and PEG were important in producing the dipeptide in high yields. It is presumed that in the PEG-added system, the enzyme and water were homogeneously dispersed in the organic medium and thus the PEG functioned as a surface-active agent. In the PEG-added system, the enzyme in water and amino acids in organic solvent was efficiently mixed and appeared together. The maximum percentage of the reaction was found with $2 \mathrm{mg}$ of PEG, 0.2 $\mathrm{mL}$ of PBS in $3 \mathrm{~mL}$ ethyl acetate. This result suggests that in an aqueous medium, $\alpha$-chymotrypsin catalyzes the hydrolytic reaction. However, in an organic solvent containing a small amount of water and PEG, it catalyzes dipeptide bond formation, which is a reverse of the hydrolysis reaction, thus changing the enzyme-catalyzed step from a hydrolytic reaction with high water concentration to a peptide bond formation with a very low water concentration.

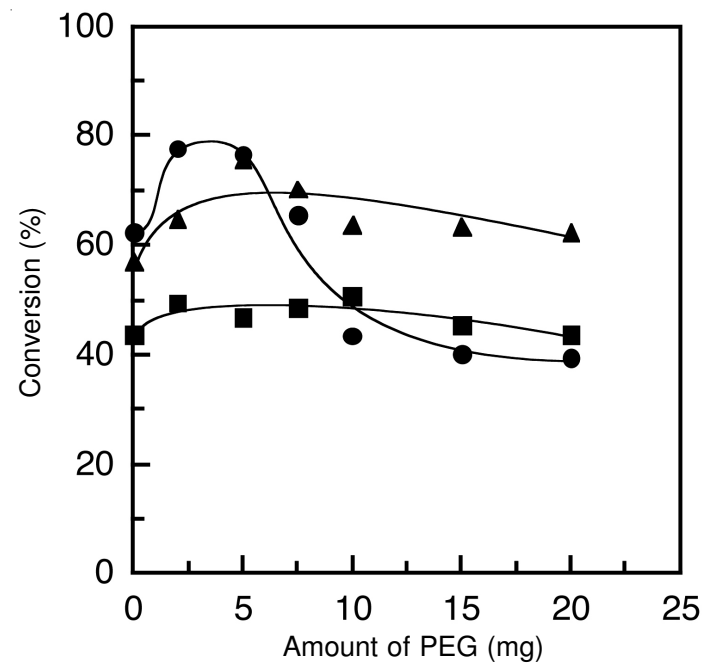

Fig. 4. Relationship between the percentage conversion of the reaction and the amount of PEG. Phosphate buffer: $0.075 \mathrm{~mL}(\square), 0.2 \mathrm{~mL}(\mathbf{})$ and $0.5 \mathrm{~mL}(\mathbf{\Delta})$

Relationship between the percentage conversion of the reaction and the reaction temperature: Fig. 5 shows the relationship between the percentage of reaction and the reaction temperature. In both the PEG-added system and the PEG-free system, the maximum activity of the enzyme was obtained at $30-35{ }^{\circ} \mathrm{C}$. At $50{ }^{\circ} \mathrm{C}$, the activity of the enzyme decreased to zero. In the lower and higher temperature ranges, the activity of the enzyme in the PEG-added system was higher than in the PEG-free system.

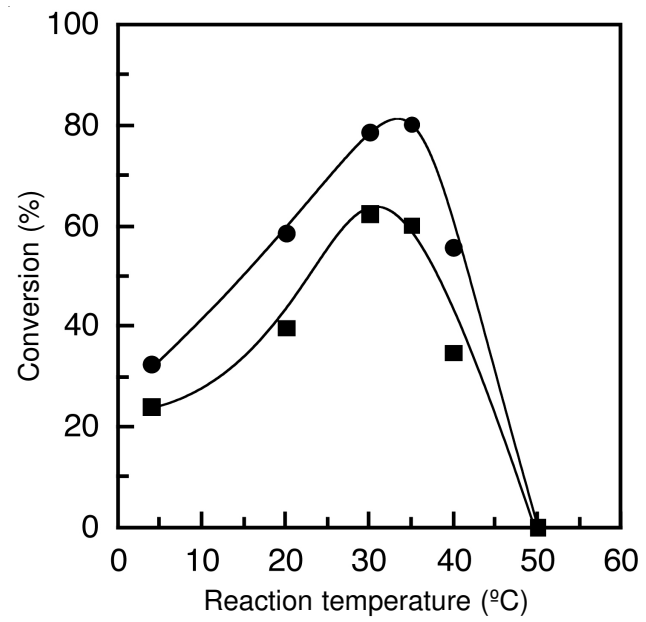

Fig. 5. Relationship between the percentage conversion of the reaction and reaction temperature for the PEG-added $(\bullet)$ and PEG-free systems (ם)

Relationship between the percentage conversion of the reaction and the reaction time: Fig. 6 is the time course of the reaction at $30{ }^{\circ} \mathrm{C}$. Throughout the reaction period, the activity of the enzyme in the PEG-added system was higher than in the PEG-free system. The percentage conversion of the reaction in the PEG-added system leveled off at approximately $40 \mathrm{~h}$. In the PEG-free system, the percentage conversion of the reaction decreased gradually after $30 \mathrm{~h}$. The other side, the new peak appeared for the GPC chromatograms after $30 \mathrm{~h}$, this peak may be a by-products. These results suggest that the PEG-added system inhibited the side reaction, for example hydrolysis of $C$-terminal protected benzyl ether. MichaelisMenten constant $\left(\mathrm{K}_{\mathrm{m}}\right)$ values obtained for both reaction systems were the same (Table-1), although the addition of PEG contributed to the reaction rate as an accelerator in this reaction system. We conclude from the $\mathrm{K}_{\mathrm{m}}$ values that PEG acted as an anti-non-competitive inhibitor for the enzyme in the PEGadded system.

\begin{tabular}{|c|c|c|}
\hline \multicolumn{3}{|c|}{$\begin{array}{c}\text { TABLE-1 } \\
\mathrm{K}_{\mathrm{m}}{\text { AND } \mathrm{V}_{\max } \text { VALUES DETERMINED }} \text { FROM LINEWEAVER-BURK PLOTS }\end{array}$} \\
\hline & $\mathrm{K}_{\mathrm{m}}(\mathrm{mmol} / \mathrm{L})$ & $\mathrm{V}_{\max }(\mathrm{mM} / \mathrm{min})$ \\
\hline PEG-added system & 38.4 & 0.72 \\
\hline PEG-free system & 37.8 & 0.33 \\
\hline
\end{tabular}

Reaction rate and Michaelis-Menten constant: The initial reaction rate $[\mathrm{v}]$ was obtained from the curve plotted between $0-7 \mathrm{~min}$ at $30^{\circ} \mathrm{C}$. In Fig. 7, the reciprocal of the reaction rate $(1 /[\mathrm{v}])$ is plotted against the reciprocal of the substrate concentration (1/[S]), according to the Lineweaver-Burk equation. The Michaelis-Menten constant $\left(\mathrm{K}_{\mathrm{m}}\right)$ and the maximum rate $\left(\mathrm{V}_{\max }\right)$ are shown in Table-1; it was obvious from Table-1 that the addition of PEG enhanced the rate of peptide synthesis. 


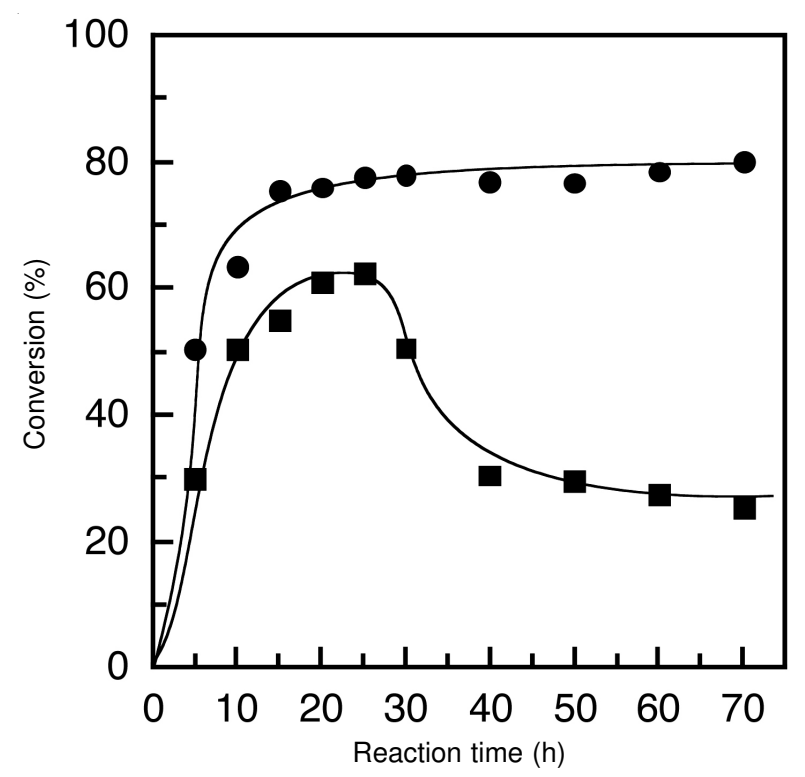

Fig. 6. Relationship between the percentage conversion of the reaction and the. Reaction time for the PEG-added (O) and PEG-free systems (ם)

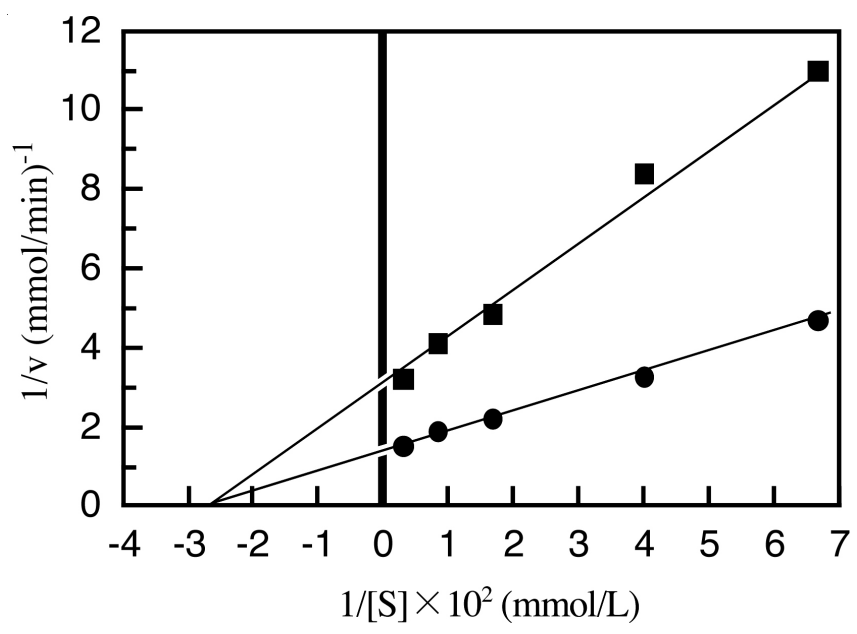

Fig. 7. Lineweaver-Burk plots for the PEG-added $(\bullet)$ and PEG-free systems (ם)

The reaction rate in the PEG-added system was about twice as fast as that in the PEG-free system, although the mechanisms responsible for the effects of PEG in this reaction are not clear. PEG, which has having both hydrophilic and hydrophobic characteristics, may have been adsorbed onto the enzyme surface in the presence of a small amount of water, due to its hydrophilic nature and then the enzyme partly covered with PEG would enhance the approach of substrates to the active site of the enzyme by this hydrophobic nature. Furthermore, this action did not damage the enzyme in an organic medium with respect to the protein structure and the active site of the enzyme. Thus, the reaction rate was enhanced in the presence of PEG. From these facts, we conclude that is possible to synthesize a dipeptide with a non-modified enzyme in an organic medium by adding PEG only. This peptide synthesis method described may be useful for obtaining a large quantity of peptide.

\section{ACKNOWLEDGEMENTS}

This work was partly supported by Grant-in-Aid for Scientific Research (C) and Strategic Project to Support the Formation of Research Bases at Private Universities: Matching Fund Subsidy from MEXT (Ministry of Education, Culture, Sports, Science and Technology).

\section{REFERENCES}

1. A.M. Klibanov, Chemtech, 16, 354 (1986).

2. A. Zaks and A.M. Klibanov, Proc. Nat. Acad. Sci. USA, 82, 3192 (1985).

3. K. Nakanishi, Y. Kimura and and R. Matsuno, Biotechnology, 4, 452 (1986).

4. J.S. Dordick, Enzym. Microbiol. Technol., 11, 194 (1989).

5. P. Lozano, D. Combes, J.L. Iborra and A. Manjon, Biotechnol. Lett., 15, 1223 (1993).

6. H. Waldmann and D. Sebastian, Chem. Rev., 94, 911 (1994).

7. R.L. Fandino, I. Gill and E.N. Vulfson, Biotechnol. Bioeng., 43, 1024 (1994).

8. H. Kitano, Y. Maeda, M. Yamamoto and R. Izumida, Macromol. Chem. Phys., 197, 4173 (1996).

9. P. Clapés, J.L. Torres and P. Adlercreutz, Bioorg. Med. Chem., 3, 245 (1995).

10. J.M. Cabral, M.R. Aires-Barros, H. Pinheiro and D.M. Prazeres, J. Biotechnol., 59, 133 (1997).

11. K. Kawashiro, H. Sugahara, S. Sugiyama and H. Hayashi, Biotechnol. Bioeng., 43, 26 (1997).

12. U. Eichhorn, A.S. Bommarius, K. Drauz and H.-D. Jakubke, J. Peptide Sci., 3, 245 (1997).

13. U. Eichhorn, K. Beck-Piotraschke, R. Schaaf and H.-D. Jakubke, J. Peptide Sci., 3, 261 (1997).

14. C. Lombard, J. Saulnier and J.M. Wallach, Protein Peptide Lett., 12, 621 (1994).

15. H. Sekizaki, K. Itoh, E. Toyota and K. Tanizawa, Chem. Pharm. Bull., 44, 1585 (1996).

16. H. Sekizaki, K. Itoh, E. Toyota and K. Tanizawa, Amino Acids, 17, 285 (1999).

17. P. Clapés, C. Morán and M.R. Infante, Biotechnol. Bioeng., 63, 333 (1999).

18. K. Nakanishi, T. Kamikubo and R. Matsumoto, Biotechnology, 3, 459 (1985).

19. H. Sekizaki, K. Itoh, A. Shibuya, E. Toyota, M. Kojoma and K. Tanizawa, Chem. Pharm. Bull., 56, 688 (2008).

20. K. Yoshinaga, S.G. Shefer and J.M. Harris, J. Bioactive Compatible Polym., 2, 49 (1987). 